\title{
ORAL ANTIDIABETICS AGENTS AVAILABLE IN INDIAN PHARMACEUTICAL MARKET: A PRICE VARIATION ANALYSIS
}

\author{
KUNTAL S THACKER, VIMESH R MISTRY*, NEETA J KANANI
}

\author{
Department of Pharmacology, Medical College Baroda, Vadodara, Gujarat, India. Email: dr.vimesh.baroda@gmail.com
}

Received: 27 November 2019, Revised and Accepted: 04 January 2020

ABSTRACT

Objective: There are hundreds of brands in Indian markets for a single drug which is manufactured by various companies and thus leads to wide variation in prices for the same drug. Hence, we decide to evaluate the variation in price of different brands of the same drug available in Indian market.

Methods: An analysis was done for comparing price variations among various drugs prescribed in diabetes mellitus. Indian Drug Review (IDR) (2019 Volume XXV Issue 4) and Current Index of Medical Specialties (CIMS) (July 2019-October 2019) were referred to know the maximum and minimum price in INR of drugs in all available strength and dosage forms being manufactured by different companies in India and percentage price variation was calculated.

Results: Wide variation in the price of several brands of oral antidiabetics is found in Indian market. In single drug, highest price variation is found for glimepiride $1 \mathrm{mg}$ tablet (1365.5\%). In fixed-dose combinations (FDCs), highest price variation is found for glimepiride + metformin ( $2 \mathrm{mg}+500 \mathrm{mg}$ ) sustain release tablet (689.2\%). Lowest price variation for FDCs was found for glimepiride + metformin ( 3 mg $+500 \mathrm{mg}$ ) tablet ( $4.8 \%$ ). Furthermore, only few oral antidiabetic agents were included in the drug pricing control order 2013. Wide variation is seen in prices of brand and generic medicines.

Conclusion: All the stakeholders should collectively make efforts to reduce price variation among the various brands so as to make them affordable and aim to improve the health status of the community.

Keywords: Price variation, Antidiabetic agents, Indian pharmaceutical market.

(C) 2020 The Authors. Published by Innovare Academic Sciences Pvt Ltd. This is an open access article under the CC BY license (http://creativecommons. org/licenses/by/4. 0/) DOI: http://dx.doi.org/10.22159/ajpcr.2020.v13i3.36498

\section{INTRODUCTION}

Developing countries spend $20-60 \%$ health budget on medicines. Up to $90 \%$ of the people in developing countries buy medicines through out-of-pocket payments and thus making medicines the largest family expenditure item after food. Due to high cost of medicines, they are unaffordable for major sections of the world population and are a major burden on government expenditure [1]. Pharmacoeconomics plays a major role in the practice of medicine in once life. In a developing country like India, price of drugs plays a major role to both physician and patient in selecting a drug for treatment. Price of the drug affects patient more than physician as selection of drug is done by a physician though the patient is a buyer. Apart from safety and efficacy, cost is also an important factor for drug to be included in the formulary and national essential medicines by government of India and cost also take into account for selection of preferred drug (P drug) by doctors.

In Indian pharmaceutical market, there is tough competition between domestic and foreign manufacturers. There are hundreds of brands in Indian markets for a single drug which is manufactured by various companies and thus leads to wide variation in prices for the same drug. There are more than 100,000 formulations available for all the categories of drugs under different brand names [2]. Cost of drug therapy is the major hurdle in effective treatment of disease and compliance toward the drug regimen. Effectiveness of the drug therapy depends on the compliance of drug by patients. Improvement in compliance can reduce the total health-care cost by both government and patient involved in the management of disease [3].

Diabetes is the most common noncommunicable disease worldwide. Diabetes mellitus is a chronic metabolic disorder, one of the major causes of morbidity and mortality which requires lifelong treatment.
Hence, the price of antidiabetic drug is the major deciding factor for the patients' compliance. The cost of therapy is high for diabetes mellitus and adversely affects the economy of low-income group family [4]. The International Diabetes Federation estimates the total number of diabetic subjects to be around 40.9 million in India and this is further set to rise to 69.9 million by the year 2025 [5]. Choice of antidiabetic agents as first-line drug or combined therapy should be based on both the pharmacological properties of the drugs (efficacy and safety) and the clinical characteristics of the patient (stage of disease, body weight, etc.). Insulin is preferred for Type- 1 diabetes mellitus and oral antidiabetic agents are preferred for Type-2 diabetes mellitus [6].

Limited studies are available in Indian scenario in which prices of different brands of same drug were compared and also comparison of prices of brand and generic of the same drug. Hence, we decided to do such analytic study, which mainly focuses on price variations of different oral antidiabetic agents and their fixed-dose combinations (FDCs) available in Indian market.

\section{METHODS}

It was an analytical type of study which includes all oral antidiabetic agents (single drug and FDC) drug formulations with same strength, while the drugs manufactured by a single company and FDCs with drugs other than oral antidiabetic agents were excluded from the study. Indian Drug Review (IDR) (2019 edition, Volume XXV Issue 4) and Current Index of Medical Specialties (CIMS) (July 2019-October 2019) were referred to know the maximum and minimum price in INR (Per 10 Tablet) of oral antidiabetic agent in all the available strength and dosage forms being manufactured by different companies in India. On the basis of this, we can know how many times the costliest brand costs more than the cheaper brands of each drug. To compare prices of 
brand drug with a generic drug, prices of generics, which were given on http://janaushadhi.gov.in/ProductList.aspx (cited on 20.11.2019) used as a source.

$$
\text { Cost ratio }=\frac{\text { Maximum cost }}{\text { Minimum cost }}
$$

Percentage cost variation was calculated by

$$
\text { Cost variation }(\%)=\frac{\text { Maximum cost }- \text { Minimum cost }}{\text { Minimum cost }} \times 100
$$

Data were analyzed using percentage and proportions.

\section{RESULTS}

We have analyzed prices of various oral antidiabetics agents marketed by several pharmaceutical companies. Tables 1-3 show percentage price variation of oral antidiabetic agents. In our analysis, wide variation is found in the prices of several brands of same antidiabetic agent in Indian market. In our study, we have analyzed single drug and various FDCs also. Among all oral drugs used for diabetes mellitus, highest percentage price variation is found for Glimepiride $1 \mathrm{mg}$ tablet (1365.5\%) followed by metformin $500 \mathrm{mg}$ sustain release (SR) tablet $(809.09 \%)$ in single drug. In single drug preparation $>60 \%$ drugs show more than $100 \%$ price variation. Least price variation is shown by glipizide $10 \mathrm{mg}$ tablet (5.5\%), acarbose $100 \mathrm{mg}$ tablet (9.78\%), teneligliptin $20 \mathrm{mg} \mathrm{FC}$ tablet (21.05\%), and pioglitazone $7.5 \mathrm{mg}$ tablet $(21.78 \%)$ in single drug preparation [Table 1].

In FDCs, 50\% FDCs show $>100 \%$ price variation and 50\% FDCs show $<100 \%$ price variation. In two drug FDCs, highest percentage price variation is found for glimepiride + metformin $(2 \mathrm{mg}+500 \mathrm{mg})$ SR tablet $(689.2 \%)$, followed by glipizide + metformin $(5 \mathrm{mg}+500 \mathrm{mg})$ tablet (644\%), glipizide + metformin $(2.5 \mathrm{mg}+400 \mathrm{mg})$ tablet $(404 \%)$, and glimepiride + metformin (2 mg + $1000 \mathrm{mg})$ SR tablet (370.5\%) [Table 2]

While lowest price variation for two drug FDCs is found for glimepiride + metformin (3 mg + $1000 \mathrm{mg}$ ) tablet (14.8\%), gliclazide + metformin (40 mg +500 mg) SR tablet (8.3\%), and glimepiride + metformin (3 mg + $500 \mathrm{mg}$ ) SR tablet (4.8\%) [Table 2]. In three drug FDCs, highest price variation is seen with glimepiride + metformin + pioglitazone (2 mg + $500 \mathrm{mg}+15 \mathrm{mg}$ ) SR tablet $(200 \%)$ followed by glimepiride + metformin + voglibose $(1 \mathrm{mg}+500 \mathrm{mg}+0.2 \mathrm{mg})$ SR tablet (164.4\%) and glimepiride + metformin + pioglitazone $(1 \mathrm{mg}+500 \mathrm{mg}+15 \mathrm{mg})$ SR tablet $(151.2 \%)$. Lowest price variation among three drug FDCs is shown by glimepiride + metformin + voglibose $(1 \mathrm{mg}+500 \mathrm{mg}+$ $0.2 \mathrm{mg}$ ) tablet $(23.6 \%)$ and glimepiride + metformin + pioglitazone $(2 \mathrm{mg}+500 \mathrm{mg}+15 \mathrm{mg})$ tablet (22.3\%) [Table 3]

On comparison of drug price which is under control of drug pricing control order (DPCO), it is found that prices of many brand drugs were higher than those which are recommended ceiling price in National

\begin{tabular}{|c|c|c|c|c|c|c|c|}
\hline Drug & Formulation & Dose & For (quantity) & Minimum price & Maximum price & Cost ratio & Cost variation (\%) \\
\hline \multirow[t]{3}{*}{ Acarbose } & Tablet & $25 \mathrm{mg}$ & 10 & 47.25 & 80.5 & 1.70 & 70.37 \\
\hline & & $50 \mathrm{mg}$ & 10 & 85 & 140.5 & 1.65 & 65.29 \\
\hline & & $100 \mathrm{mg}$ & 10 & 91.27 & 100.2 & 1.09 & 9.78 \\
\hline \multirow[t]{2}{*}{ Glibenclamide } & Tablet & $2.5 \mathrm{mg}$ & 10 & 2.66 & 6.11 & 2.29 & 129.69 \\
\hline & & $5 \mathrm{mg}$ & 10 & 5.83 & 13.43 & 2.30 & 130.36 \\
\hline \multirow[t]{3}{*}{ Gliclazide } & Tablet & $30 \mathrm{mg}$ & 10 & 18.22 & 77.7 & 4.26 & 326.45 \\
\hline & & $40 \mathrm{mg}$ & 10 & 12.12 & 50 & 4.12 & 312.54 \\
\hline & & $80 \mathrm{mg}$ & 10 & 20 & 80 & 4 & 300 \\
\hline \multirow[t]{4}{*}{ Glimepiride } & Tablet & $1 \mathrm{mg}$ & 10 & 14.5 & 212.5 & 14.65 & 1365.51 \\
\hline & & $2 \mathrm{mg}$ & 10 & 23 & 99.2 & 4.31 & 331.30 \\
\hline & & $3 \mathrm{mg}$ & 10 & 31.25 & 128.5 & 4.11 & 311.2 \\
\hline & & $4 \mathrm{mg}$ & 10 & 38.1 & 162 & 4.25 & 325.19 \\
\hline \multirow[t]{3}{*}{ Glipizide } & Tablet & $5 \mathrm{mg}$ & 10 & 4.36 & 13.03 & 2.98 & 198.85 \\
\hline & & $10 \mathrm{mg}$ & 10 & 18 & 19 & 1.05 & 5.55 \\
\hline & SR tablet & $5 \mathrm{mg}$ & 10 & 1.48 & 6.12 & 4.13 & 313.51 \\
\hline \multirow{6}{*}{ Metformin } & & $500 \mathrm{mg}$ & 10 & 4.4 & 20.05 & 4.55 & 355.68 \\
\hline & & $850 \mathrm{mg}$ & 10 & 11.12 & 32 & 2.87 & 187.76 \\
\hline & & $1000 \mathrm{mg}$ & 10 & 11.2 & 57.46 & 5.13 & 413.03 \\
\hline & SR tablet & $500 \mathrm{mg}$ & 10 & 4.4 & 40 & 9.09 & 809.09 \\
\hline & & $850 \mathrm{mg}$ & 10 & 10.91 & 37 & 3.39 & 239.13 \\
\hline & & $1000 \mathrm{mg}$ & 10 & 24.1 & 64.5 & 2.67 & 167.63 \\
\hline \multirow[t]{2}{*}{ Miglitol } & Tablet & $25 \mathrm{mg}$ & 10 & 59.16 & 134 & 2.26 & 126.50 \\
\hline & & $50 \mathrm{mg}$ & 10 & 108 & 204 & 1.88 & 88.88 \\
\hline \multirow[t]{3}{*}{ Pioglitazone } & Tablet & $7.5 \mathrm{mg}$ & 10 & 52.82 & 64.25 & 1.21 & 21.63 \\
\hline & & $15 \mathrm{mg}$ & 10 & 15 & 67.6 & 4.50 & 350.66 \\
\hline & & $30 \mathrm{mg}$ & 10 & 20 & 83.5 & 4.17 & 317.5 \\
\hline \multirow[t]{3}{*}{ Repaglinide } & Tablet & $0.5 \mathrm{mg}$ & 10 & 19.9 & 48.4 & 2.43 & 143.21 \\
\hline & & $1 \mathrm{mg}$ & 10 & 39.9 & 78.9 & 1.97 & 97.74 \\
\hline & & $2 \mathrm{mg}$ & 10 & 75 & 124.8 & 1.664 & 66.4 \\
\hline \multirow[t]{2}{*}{ Voglibose } & Tablet & $0.2 \mathrm{mg}$ & 10 & 21 & 87.75 & 4.17 & 317.85 \\
\hline & & $0.3 \mathrm{mg}$ & 10 & 29.5 & 118.52 & 4.01 & 301.76 \\
\hline \multirow[t]{2}{*}{ Teneligliptin } & Tablet & $20 \mathrm{mg}$ & 10 & 55 & 127 & 2.30 & 130.90 \\
\hline & **FC tablet & $20 \mathrm{mg}$ & 10 & 95 & 115 & 1.21 & 21.05 \\
\hline \multirow[t]{2}{*}{ Nateglinide } & Tablet & $60 \mathrm{mg}$ & 10 & 30.76 & 86 & 2.79 & 179.58 \\
\hline & & $120 \mathrm{mg}$ & 10 & 51.27 & 157 & 3.06 & 206.22 \\
\hline
\end{tabular}

Table 1: Price variation of single drug formulation of oral antidiabetic agents

*MD: Mouth dissolving **FC: Film coated. SR: Sustain release 
Table 2: Price variation of two drugs FDCs of oral antidiabetic agents

\begin{tabular}{|c|c|c|c|c|c|c|c|}
\hline Drug & Formulation & Dose & $\begin{array}{l}\text { For } \\
\text { (quantity) }\end{array}$ & $\begin{array}{l}\text { Minimum } \\
\text { price }\end{array}$ & Maximum price & Cost ratio & Cost variation $(\%)$ \\
\hline \multirow[t]{3}{*}{ Glibenclamide + metformin } & Tablet & $1.25 \mathrm{mg}+250 \mathrm{mg}$ & 10 & 12.5 & 22 & 1.76 & 76 \\
\hline & & $2.5 \mathrm{mg}+400 \mathrm{mg}$ & 10 & 10.4 & 33 & 3.17 & 217.30 \\
\hline & & $5 \mathrm{mg}+500 \mathrm{mg}$ & 10 & 13 & 57 & 4.38 & 338.46 \\
\hline \multirow[t]{4}{*}{ Gliclazide + metformin } & Tablet & $40 \mathrm{mg}+500 \mathrm{mg}$ & 10 & 35 & 70 & 2 & 100 \\
\hline & & $80 \mathrm{mg}+500 \mathrm{mg}$ & 10 & 28.6 & 106 & 3.70 & 270.62 \\
\hline & SR tablet & $40 \mathrm{mg}+500 \mathrm{mg}$ & 10 & 60 & 65 & 1.08 & 8.33 \\
\hline & & $80 \mathrm{mg}+500 \mathrm{mg}$ & 10 & 62 & 106 & 1.70 & 70.96 \\
\hline \multirow[t]{11}{*}{ Glimepiride + metformin } & Tablet & $1 \mathrm{mg}+500 \mathrm{mg}$ & 10 & 26.4 & 73 & 2.76 & 176.51 \\
\hline & & $2 \mathrm{mg}+500 \mathrm{mg}$ & 10 & 42.5 & 70 & 1.64 & 64.70 \\
\hline & & $1 \mathrm{mg}+1000 \mathrm{mg}$ & 10 & 62 & 99.7 & 1.60 & 60.80 \\
\hline & & $3 \mathrm{mg}+1000 \mathrm{mg}$ & 10 & 93.74 & 107.66 & 1.14 & 14.84 \\
\hline & & $4 \mathrm{mg}+1000 \mathrm{mg}$ & 10 & 69 & 127 & 1.84 & 84.05 \\
\hline & SR tablet & $1 \mathrm{mg}+500 \mathrm{mg}$ & 10 & 22.9 & 96.6 & 4.21 & 321.83 \\
\hline & & $2 \mathrm{mg}+500 \mathrm{mg}$ & 10 & 29.9 & 236 & 7.89 & 689.29 \\
\hline & & $2 \mathrm{mg}+1000 \mathrm{mg}$ & 10 & 33.9 & 159.5 & 4.70 & 370.50 \\
\hline & & $3 \mathrm{mg}+500 \mathrm{mg}$ & 10 & 76.33 & 80 & 1.04 & 4.80 \\
\hline & & $3 \mathrm{mg}+1000 \mathrm{mg}$ & 10 & 65 & 117 & 1.8 & 80 \\
\hline & & $4 \mathrm{mg}+1000 \mathrm{mg}$ & 10 & 90 & 126.3 & 1.40 & 40.33 \\
\hline \multirow[t]{2}{*}{ Glipizide + metformin } & Tablet & $2.5 \mathrm{mg}+400 \mathrm{mg}$ & 10 & 5.2 & 26.25 & 5.04 & 404.80 \\
\hline & & $5 \mathrm{mg}+500 \mathrm{mg}$ & 10 & 6.72 & 50 & 7.44 & 644.04 \\
\hline \multirow[t]{3}{*}{ Glimepiride + pioglitazone } & Tablet & $1 \mathrm{mg}+15 \mathrm{mg}$ & 10 & 19.25 & 89.5 & 4.64 & 364.93 \\
\hline & & $2 \mathrm{mg}+15 \mathrm{mg}$ & 10 & 30.9 & 115 & 3.72 & 272.16 \\
\hline & & $2 \mathrm{mg}+30 \mathrm{mg}$ & 10 & 69 & 120 & 1.73 & 73.91 \\
\hline \multirow[t]{3}{*}{ Pioglitazone + metformin } & Tablet & $15 \mathrm{mg}+500 \mathrm{mg}$ & 10 & 22.5 & 84 & 3.73 & 273.33 \\
\hline & SR tablet & $15 \mathrm{mg}+500 \mathrm{mg}$ & 10 & 32.85 & 93 & 2.83 & 183.10 \\
\hline & & $30 \mathrm{mg}+500 \mathrm{mg}$ & 10 & 31.9 & 86.2 & 2.70 & 170.21 \\
\hline \multirow{4}{*}{ Voglibose + metformin } & Tablet & $0.2 \mathrm{mg}+500 \mathrm{mg}$ & 10 & 46.5 & 158.78 & 3.41 & 241.46 \\
\hline & & $0.3 \mathrm{mg}+500 \mathrm{mg}$ & 10 & 34.9 & 97 & 2.77 & 177.93 \\
\hline & SR tablet & $0.2 \mathrm{mg}+500 \mathrm{mg}$ & 10 & 30.9 & 100 & 3.23 & 223.62 \\
\hline & & $0.3 \mathrm{mg}+500 \mathrm{mg}$ & 10 & 58.9 & 115 & 1.95 & 95.24 \\
\hline Teneligliptin + metformin & Tablet & $20 \mathrm{mg}+500 \mathrm{mg}$ & 10 & 79 & 129 & 1.63 & 63.29 \\
\hline
\end{tabular}

FDC: Fixed-dose combination, SR: Sustain release

Table 3: Price variation of three drugs FDCs of oral antidiabetic agents

\begin{tabular}{|c|c|c|c|c|c|c|c|}
\hline Drug & Formulation & Dose & $\begin{array}{l}\text { For } \\
\text { (quantity) }\end{array}$ & $\begin{array}{l}\text { Minimum } \\
\text { price }\end{array}$ & $\begin{array}{l}\text { Maximum } \\
\text { price }\end{array}$ & $\begin{array}{l}\text { Cost } \\
\text { ratio }\end{array}$ & $\begin{array}{l}\text { Cost variation } \\
(\%)\end{array}$ \\
\hline \multirow[t]{6}{*}{ Glimepiride + metformin + pioglitazone } & \multirow[t]{2}{*}{ Tablet } & $1 \mathrm{mg}+500 \mathrm{mg}+15 \mathrm{mg}$ & 10 & 49 & 95 & 1.93 & 93.87 \\
\hline & & $2 \mathrm{mg}+500 \mathrm{mg}+15 \mathrm{mg}$ & 10 & 65.4 & 80 & 1.22 & 22.32 \\
\hline & \multirow[t]{4}{*}{ SR tablet } & $1 \mathrm{mg}+500 \mathrm{mg}+15 \mathrm{mg}$ & 10 & 42 & 105.5 & 2.51 & 151.19 \\
\hline & & $2 \mathrm{mg}+500 \mathrm{mg}+15 \mathrm{mg}$ & 10 & 56 & 168 & 3 & 200 \\
\hline & & $1 \mathrm{mg}+1000 \mathrm{mg}+15 \mathrm{mg}$ & 10 & 75 & 109.9 & 1.46 & 46.53 \\
\hline & & $2 \mathrm{mg}+1000 \mathrm{mg}+15 \mathrm{mg}$ & 10 & 85 & 119.9 & 1.41 & 41.05 \\
\hline \multirow{5}{*}{ Glimepiride + metformin + voglibose } & Tablet & $2 \mathrm{mg}+500 \mathrm{mg}+0.2 \mathrm{mg}$ & 10 & 89 & 149.9 & 1.68 & 68.42 \\
\hline & \multirow[t]{4}{*}{ SR tablet } & $1 \mathrm{mg}+500 \mathrm{mg}+0.2 \mathrm{mg}$ & 10 & 59 & 156 & 2.64 & 164.40 \\
\hline & & $2 \mathrm{mg}+500 \mathrm{mg}+0.2 \mathrm{mg}$ & 10 & 69 & 186 & 2.69 & 169.56 \\
\hline & & $1 \mathrm{mg}+500 \mathrm{mg}+0.3 \mathrm{mg}$ & 10 & 69 & 129.8 & 1.88 & 88.11 \\
\hline & & $2 \mathrm{mg}+500 \mathrm{mg}+0.3 \mathrm{mg}$ & 10 & 79 & 145.5 & 1.84 & 84.17 \\
\hline
\end{tabular}

FDC: Fixed-dose combination

Pharmaceutical Pricing Authority - 2018. We have also found that very few drugs are included in DPCO [7] [Table 4]

Wide differences are found in prices of brand drugs with the generic drug of the same product. Prices of brand drugs are compared with generic prices available on the website http://janaushadhi.gov.in/ProductList. aspx [Accessed on November 22, 2019]. Prices of brand drug of a same product are much higher than its generic version [Table 5].

\section{DISCUSSION}

In our analysis, more number of single as well as FDCs is found with high price variability. Similar type of price variability is found in another study by Tiwari and Yadav [8]. Not only in the oral antidiabetic agents but also such high price variation is also found in another group of drugs such as drugs used for coagulation disorders, antihypertensive, anxiolytics, hypolipidemics, and nonsteroidal anti-inflammatory drugs in Indian market [1,9-12]. Hence, from all these studies, we come to know that in India a strict policy must require to control high price variation by different companies.

These wide variations in the prices of different formulations of the same drug have severe economic implications on the Indian population by disturbing their health budget [11]. The high price of drugs can lead to economic burden which results in decreased compliance or even noncompliance. Noncompliance leads to incomplete treatment which 
tends to increase morbidity or mortality. Nonaffordability of medication is found to be associated with nonadherence to prescription medication by patient [13].

The drug prices available in CIMS and IDR are compared, as they are readily available source of drug information and are updated regularly. Drugs used in the management of diabetes mellitus are selected as it is one of the major causes of morbidity and mortality and the treatment requires continuous prescription drug use.

In India, more than one pharmaceutical company sells a particular drug under different brand names along with the innovator company. This situation has led to greater price variation among drugs marketed. Pharma sector in India, which is predominantly a branded generic market, i.e., multiple companies sell a particular drug under different brand names. Hence, the number of brands available in the market is very high. Lack of information or imperfect information, government rules and pricing policies, the costs of raw materials, distribution and marketing, economic target of the parent company, and target return on investment are various factors which contribute to this phenomenon [14]. In India, almost all medicines in India are sold under a brand/trade name and maybe branded medicines or branded-generic which simply called generics worldwide. Actually, there are very few branded medicines in the Indian market. The majority of drugs in Indian market are branded generic in nature. Many pharmaceutical companies manufacture two types of products for the same molecule

Table 4: Comparison of drug price in the market with prices recommended under DPCO 2013

\begin{tabular}{llll}
\hline Drug & $\begin{array}{l}\text { Dose and formulation } \\
\text { (quantity) }\end{array}$ & $\begin{array}{l}\text { Maximum } \\
\text { price in } \\
\text { market } \\
\text { (rupees) }\end{array}$ & $\begin{array}{l}\text { Ceiling } \\
\text { price in } \\
\text { (rupees) in } \\
\text { NPPA-2018 }\end{array}$ \\
\hline Glimepiride & 1 mg tablet (10) & 212.5 & 33.7 \\
Metformin & 2 mg tablet (10) & 99.2 & 53.5 \\
& 500 mg tablet (10) & 20.05 & 14.1 \\
& 850 mg tablet (10) & 32 & 28.5 \\
& 1000 mg tablet (10) & 57.46 & 33.8 \\
& 500 mg SR tablet (10) & 40 & 17.9 \\
& 850 mg SR tablet (10) & 37 & 22.5 \\
& 1000 mg SR tablet (10) & 64.5 & 34.2 \\
\hline
\end{tabular}

SR: Sustain release, DPCO: Drug pricing control order, NPPA: National

Pharmaceutical Pricing Authority like the branded product which they advertise and push through doctors and branded-generic which are pushed by retailers [15]. Some studies have revealed that retailer margins for the branded generics are very large (200-1000\%) compared to branded drugs (25-30\%). Therefore, the ultimate consumer, i.e., patient is not benefited much by preferring branded-generic versions to its branded version. Hence, the actual benefit is not passing on the consumer [16].

Government order for prescribing drugs by their generic name but that not provide surety that brand with lower cost will be dispensed by the pharmacist. There is a myth among the majority common people including a fraction of prescribing physicians that costlier branded drugs are superior than their generic equivalents. The costly brand of same generic drug is scientifically proved to be in no way superior to its economically cheaper counterpart [17]. Many studies found no significant difference in medication effectiveness between generic and patent drugs [18]. Hence, the general population should be encouraged to use generic medicines.

The DPCO, 2018 list of price-controlled drugs includes only glimepiride and metformin. In the World Health Organization model list of essential medicines, among oral antidiabetic drugs, only 2 drugs of the total 11 drugs, i.e., gliclazide (30/60/80 mg) and metformin $500 \mathrm{mg}$ were included in the study, while other newer and more effective drugs are not included in the list $[7,19]$. Now is the time that the government takes strict actions to regulate the prices which can be afforded by a common man. Many newer and commonly used drugs included in the National List of Essential Medicines. The government should also cap the prices of nonscheduled drugs. Government checks the high price of drugs by provision of incentives to drug manufacturers through other means like tax benefits (similar to orphan drugs). Use of good quality generic drugs, which are bioequivalent to brand name drug, can help contain prescription drug spending. The government of India has opened few generic drug stores in some states that sell generic medicines manufactured by public sector companies. The quality of generic medicines available at these stores at cheaper rates should be checked and compared with popular brands, and the results should be widely published so the general population becomes aware of this [20].

It is felt that physicians could provide better services and reduce costs of drugs if information about drug prices was readily available. Studies have shown that providing a manual of comparative drug prices along with prescribing advice to physicians reduced their patients' drug expense. Concept of $\mathrm{P}$ drug also helps in selection of cheap and effective drug for patients [21]. The importance of drug price and its

Table 5: Comparison of prices of brand drugs with generic drugs of same drug

\begin{tabular}{|c|c|c|c|c|}
\hline Drug & Dose and formulation (quantity) & Minimum price & Maximum price & Generic price (Jan Aushadhi) \\
\hline Acarbose & $50 \mathrm{mg}$ tablet $(10)$ & 85 & 140.5 & 55.9 \\
\hline \multirow{2}{*}{ Glibenclamide } & $2.5 \mathrm{mg}$ tablet $(10)$ & 2.66 & 6.11 & 2.6 \\
\hline & $5 \mathrm{mg}$ tablet $(10)$ & 5.83 & 13.43 & 4.05 \\
\hline \multirow[t]{3}{*}{ Gliclazide } & $40 \mathrm{mg}$ tablet $(10)$ & 12.12 & 50 & 11.93 \\
\hline & $60 \mathrm{mg}$ tablet $(10)$ & 39 & 131.42 & 37.62 \\
\hline & $80 \mathrm{mg}$ tablet $(10)$ & 20 & 80 & 20.25 \\
\hline \multirow[t]{3}{*}{ Glimepiride } & $1 \mathrm{mg}$ tablet $(10)$ & 14.5 & 212.5 & 3.8 \\
\hline & 3 mg tablet (10) & 31.25 & 128.5 & 3.78 \\
\hline & $4 \mathrm{mg}$ tablet $(10)$ & 38.1 & 162 & 4.37 \\
\hline Glipizide & $5 \mathrm{mg}$ tablet $(10)$ & 4.36 & 13.03 & 2.5 \\
\hline \multirow[t]{4}{*}{ Metformin } & $500 \mathrm{mg}$ tablet $(10)$ & 4.4 & 20.05 & 5.15 \\
\hline & 500 mg SR tablet (10) & 4.4 & 40 & 8.85 \\
\hline & 850 mg SR tablet (10) & 10.91 & 37 & 12.38 \\
\hline & $1000 \mathrm{mg}$ SR tablet (10) & 24.1 & 64.5 & 11.05 \\
\hline Pioglitazone & $15 \mathrm{mg}$ tablet $(10)$ & 15 & 67.6 & 6.75 \\
\hline \multirow[t]{2}{*}{ Voglibose } & $0.2 \mathrm{mg}$ tablet $(10)$ & 21 & 87.75 & 9.61 \\
\hline & $0.3 \mathrm{mg}$ tablet $(10)$ & 29.5 & 118.52 & 9.92 \\
\hline Teneligliptin & $20 \mathrm{mg} * \mathrm{FC}$ tablet $(10)$ & 95 & 115 & 49.5 \\
\hline
\end{tabular}

*FC: Film coated. SR: Sustain release 
impact on general population should be part of the early learning stage. Hence, pharmacoeconomics must be included in undergraduate and postgraduate medical education curriculum to ensure provision of better and economical health-related services [12]. Doctor's awareness about the cost varies among different brands and its same generic version plays an important role in decreasing patient's drug expense [22].

Pharmacists also play an important role by dispensing the most expensive brands for higher profit margin. They may also have tie-up with particular companies, selectively stocking only their products. There is some pharmacist that does not give the actual brand written by the prescriber and they change the brand and give some costly drug. Pharmacists are earning from that costlier brand. Pharmacists are well aware of the drug prices so they should dispense generic medicines with low cost and high efficacy $[23,24]$. Pharmacists play a key role in providing assistance on the use of generic medicines [25].

Following reasons could be present behind this huge variation in the prices [26]

1. The existing marketing structure of the pharmaceutical industry

2. Imperfect or improper information to the doctors and patients

3. High cost of raw materials which increase manufacturing cost

4. Government regulations and policies for pricing of drugs and their implementation

5. To provide better quality of medication, clinicians selectively prescribe medication from reputed companies even though they are costly.

The limitation of this study is limited; numbers of brand drugs are given in CIMS and IDR. There were many other brand drugs available on online websites and other books. Hence, a similar study can be done which also take in account other brand drugs available so we will get a better idea of price variation.

\section{CONCLUSION}

From this study, we come to the conclusion that there is a wide variation in prices of various oral antidiabetic agents used for Type- 2 diabetes mellitus. Reduction in price variation and making it affordable to improve the compliance of medicines by patients in the community helps in reduction of the economic burden on government. "Health for all" can only be achieved by efforts from patients, doctors, pharmacists, manufacturing companies, and regulatory agencies.

\section{AUTHORS' CONTRIBUTIONS}

Dr. Kuntal Thacker - Data collection from CIMS and IDR, Dr. Neeta Kanani - Preparation of manuscript, Dr. Vimesh Mistry- Design the research study and editing of manuscript as per journal guidelines.

\section{ACKNOWLEDGMENT}

None.

\section{CONFLICTS OF INTEREST}

None.

\section{SOURCE OF FUNDING}

Nil.

\section{REFERENCES}

1. Neeta JK, Mistry VR. Price variation analysis of various drugs used for thromboembolic disorders currently available in Indian pharmaceutical market. Int J Res Pharm Pharm 2019;8:294-301.

2. Rataboli PV, Garg A. Confusing brand names: Nightmare of medical profession. J Postgrad Med 2005;51:13-6.

3. Shankar PR, Subish P, Bhandari RB, Mishra P, Saha AC. Ambiguous pricing of topical dermatological products: A survey of brands from two South Asian countries. J Pak Assoc Dermatol 2006;16:134-40.

4. Ramanna MK, Ruckmani A, Janti SS, Eerike M, Prabu RL. Burden of therapy in patients suffering from diabetes mellitus and hypertension. Int J Pharm Pharm Sci 2017;9:210-5.

5. UK Essays. Oral Antidiabetic Drugs Available in Indian Market Economics Essay; 2018. Available from: https:/www.ukessays.com/ essays/economics/oral-antidiabetic-drugs-available-in-indian-marketeconomics-essay.php?vref=1. [Last accessed on 2019 Nov 22].

6. Tripathi KD. Insulin, Oral Hypoglycaemic Drugs and Glucagon. In: Essential of Medical Pharmacology. $7^{\text {th }}$ ed. New Delhi, India: Jaypee Brothers Medical Publishers Private Limited; 2013. p. 258-81.

7. Drug Price Control Order; 2013. Available from: http://www.nppaindia. nic.in/dpco2013.pdf. [Last accessed on 2019 Nov 22].

8. Tiwari A, Yadav P. Pharmaco-economic study of antidiabetic drugs. Int J Manag Appl Sci 2015;1:63-5.

9. Kumar R, Manu C, Singh DJ, Lakhani P, Tutu S, Dixit RK. The extent of price variation amongst branded antihypertensive drugs and its association with number of pharmaceutical companies. Int J Res Med Sci 2015;3:2800-6.

10. Chawan VS, Badwane SV, Gawand KV, Chhaya MU. Analysis of price variation amongst different formulations of anxiolytic drugs available in Indian market. Int J Res Med Sci 2016;4:2398-401.

11. Mamatha KR, Vishnu K. Price variation analysis of various brands of oral hypolipidemic drugs available in Indian pharmaceutical market. Int J Res Pharmacol Pharmacother 2017;6:381-8.

12. Patel BS, Chavda FM, Mundhava SG. Cost variation analysis of single nonsteroidal anti-inflammatory agents available in Indian market: An economic perspective. Int J Pharm Sci Res 2016;7:130-40.

13. Eaddy MT, Cook CL, O’Day K, Burch SP, Cantrell CR. How patient cost-sharing trends affect adherence and outcomes: A literature review. P T 2012;37:45-55.

14. Atal S, Atal S, Deshmankar B, Nawaz SA. Cost analysis of commonly used drugs under price control in India: Assessing the effect of drug price control order on brand price variation. Int J Pharm Pharm Sci 2016;8:315-21.

15. Singal GL, Nanda A, Kotwani A. A comparative evaluation of price and quality of some branded versus branded-generic medicines of the same manufacturer in India. Indian J Pharmacol 2011;43:131-6.

16. Sood R. Generic, Drug Companies, Fleecing Patients. The Tribune. Chandigarh, India, Himachal Plus; 2010. Available from: http://www. tribuneindia.com/2010/20100210/himplus.htm\#1. [Last accessed on 2019 Nov 20].

17. Morgan SG, Lee A. Cost-related non-adherence to prescribed medicines among older adults: A cross-sectional analysis of a survey in 11 developed countries. BMJ Open 2017;7:e014287.

18. Sari SP, Putri ID, Nursanti B. Cost-effectiveness analysis of ceftriaxone generic and patent in children with typhoid. Int J Appl Pharm 2018;10:76-80.

19. Parasiya SK, Balamuralidhara V, Kumar TM, Dave A, Gujarati R, Shukla A. Need for drug price control in India. Int J Drug Reg Aff 2018;1:12-8.

20. Kotwani A. Commentary: Will generic drug stores improve access to essential medicines for the poor in India? J Public Health Policy 2010;31:178-84.

21. Frazier LM, Brown JT, Divine GW, Fleming GR, Philips NM, Siegal WC, et al. Can physician education lower the cost of prescription drugs? A prospective, controlled trial. Ann Intern Med 1991;115:116-21.

22. Mehani R, Sharma P. Cost variation analysis of oral anti-diabetic drugs. Int J Basic Clin Pharmacol 2018;7:1709-14.

23. Sharma N, Mehta M, Dureja H, Chandra A. Pharmacoeconomic od antidiabetic drugs. Asian J Pharm 2018;12:1324-8.

24. Mamdani B. Drug deals. Indian J Med Ethics 2005;2:63-4.

25. Lavanya D, Dhivya K, Deekshitha P, Pravallika S, Kesini M. Attitude towards generic formulations usage: Narrowing the gap between pharmacist and physicians. Int J Pharm Pharm Sci 2019;11:117-20.

26. Mehar M, Shrivastav A, Jiwane D, Keer A. A cost analysis study of oral hypoglycemic drugs available in Indian market. World J Pharm Pharm Sci 2018;7:1237-45. 